\title{
ANALISIS KARAKTERISTIK DAN BIAYA KECELAKAAN LALU LINTAS DI KABUPATEN JEMBER
}

\author{
Karina Dea Puspita' ${ }^{1)}$ (Willy Kriswardhana ${ }^{1}$, dan Nunung Nuring Hayati' ${ }^{2)}$
}

1) Jurusan Teknik Sipil, Universitas Jember, Jember, Jawa Timur

2) Program Studi Perencanaan Wilayah Kota, Universitas Jember, Jember, Jawa Timur

willy.teknik@unej.ac.id

\begin{abstract}
Jember regency has a population that is increasing every year, causing traffic density. However, the facilities did not get so much improvement as the population did, therefore the number of traffic accidents increased. A traffic accident has an impact to increase the amount of poverty because there is so much cost to spend, either cost for when the accident happened or after the accident happened for healing cost. This study aims to analyze the characteristics and costs of traffic accidents to reduce the number of traffic accidents in Jember using the Gross Output (Human Capital) method. The results of the Gross Output (Human Capital) method obtained the cost of accident victims in Jember for three years (2017-2019) of IDR 162,010,233,179 and the cost of traffic accidents in Jember for three years (2017-2019) of IDR 192,779,704,983.
\end{abstract}

Keywords: accident characteristics, accident cost, gross output method

\begin{abstract}
ABSTRAK
Kabupaten Jember memiliki penduduk yang bertambah setiap tahunnya, sehingga menyebabkan kepadatan lalu lintas. Namun, pertumbuhan sarana dan prasarana yang ada tidak sejalan dengan pertumbuhan lalu lintas, mengakibatkan bertambahnya kecelakaan lalu lintas. Dampak dari kecelakaan lalu lintas yaitu kenaikan pada angka kemiskinan karena menimbulkan banyak pengeluaran biaya, seperti biaya ketika kecelakaan maupun biaya sesudah terjadi kecelakaan, serta biaya hilangnya produktivitas akibat terjadinya kecelakaan. Penelitian ini untuk menghitung banyaknya kerugian biaya yang ditimbulkan akibat kecelakaan lalu lintas yang didapat dari menganalisis karakteristik kecelakaan berdasarkan keadaan korban dengan menggunakan metode Gross Output (Human Capital). Hasil dari metode Gross Output (Human Capital) diperoleh angka biaya korban kecelakaan di Kabupaten Jember selama tiga tahun (2017-2019) sebesar Rp. 162,010,233,179 dan angka biaya kecelakaan lalu lintas di Kabupaten Jember selama tiga tahun (2017-2019) sebesar Rp. 192,779,704,983.
\end{abstract}

Kata kunci: karakteristik kecelakaan, biaya kecelakaan, metode gross output 


\section{PENDAHULUAN}

Kabupaten Jember mengalami pertambahan penduduk setiap tahunnya. Hal tersebut berdampak pada peningkatan mobilitas, sehingga menyebabkan terjadinya pertambahan kepadatan lalu lintas. Namun, pertumbuhan sarana dan prasarana transportasi lebih lambat dibandingkan dengan pertumbuhan lalu lintas, sehingga mengakibatkan bertambahnya angka kecelakaan lalu lintas. Berdasarkan data dari Satlantas Polres Jember selama tahun 2017-2019 terdapat 3,543 kasus kecelakaan lalu lintas. Peningkatan angka kecelakaan lalu lintas dipengaruhi oleh beberapa faktor. Faktor tersebut digolongkan menjadi tiga jenis, yaitu faktor manusia, faktor kendaraan dan faktor jalan dan lingkungan (Ogden, 1996). Beberapa penelitian yang pernah dilakukan memberikan hasil yaitu penyebab kecelakaan lalu lintas yang dominan adalah faktor manusia (Raj, Datta, V, Singh, \& V, 2011; Azizurrohman, Hayati, \& Kriswardhana, 2018; Kriswardhana et al., 2019). Studi terkait penyebab kecelakaan lalu lintas di Jember menyebutkan bahwa pengalaman berkendara dan usia menjadi faktor dominan penyebab kecelakaan (Kriswardhana et al., 2019).
Dampak dari kecelakaan lalu lintas yaitu kenaikan pada angka kemiskinan karena menimbulkan banyak pengeluaran biaya, seperti biaya ketika kecelakaan maupun biaya sesudah terjadi kecelakaan, serta biaya hilangnya produktivitas akibat terjadinya kecelakaan. Kerugian yang dialami akibat kecelakaan lalu lintas berdampak pada kondisi kondisi ekonomi sosial wilayah tersebut.

Terdapat beberapa penelitian yang telah dilakukan sebelumnya mengenai biaya kecelakaan, antara lain menyatakan bahwa metode Gross Output (Human Capital) digunakan untuk menghitung kerugian ekonomi daerah akibat kecelakaan lalu lintas, melalui cara menghitung jumlah kecelakaan lalu lintas yang sudah terjadi kemudian dianalisis besaran kerugian yang dialami (Farida \& Santosa, 2018). Penelitian lain dalam perhitungan biaya kecelakaan dilakukan di Universitas Muhammadiyah Malang menggunakan metode Willingness to Pay dan metode Gross Output (Human Capital) (Rozy, 2010). Suatu penelitian menghasilkan biaya kecelakaan berdasarkan jenis korban. Kecelakaan fatal menelan biaya Rp 263 juta, sedangkan luka ringan Rp 1.9 juta (Sugiyanto, 2017).

Penelitian ini menggunakan metode Gross Output (Human Capital). Metode 
Gross Output (Human Capital) meninjau keadaan korban kecelakaan lalu lintas untuk menganalisis karakteristik kecelakaan yang digunakan untuk menghitung timbulnya biaya kecelakaan lalu lintas.

\section{KAJIAN PUSTAKA}

\subsection{Kecelakaan Lalu Lintas}

Berdasarkan Undang-undang Nomor 22 Tahun 2009 mengenai Lalu Lintas dan Angkutan Jalan, yang dimaksud dengan kecelakaan lalu lintas yaitu kejadian yang tidak dapat dikira dan tidak direncanakan yang berada di jalan dan melibatkan dengan atau tanpa pengguna jalan lain yang menimbulkan korban atau kerugian harta benda.

\subsection{Karakteristik kecelakaan lalu lintas}

Karakteristik kecelakaan lalu lintas dikelompokkan menjadi 3 macam menurut Undang-undang Nomor 22 Tahun 2009 Pasal 229, yaitu:

1. Kecelakaan yang berdampak pada kerusakan kendaraan merupakan kecelakaan lalu lintas ringan.

2. Kecelakaan yang menyebabkan cedera ringan dan kerusakan kendaraan merupakan
3. Kecelakaan yang menyebabkan kematian atau cedera berat merupakan kecelakaan lalu lintas berat.

Berdasarkan Peraturan Pemerintah Nomor 43 Tahun 1993 Pasal 93, terdapat beberapa kriteria keparahan korban kecelakaan, yaitu:

1. Korban meninggal dunia, adalah korban yang telah meninggal dunia yang disebabkan oleh kecelakaan lalu lintas yang dihitung dalam waktu paling lama 30 (tiga puluh) hari setelah terjadinya kecelakaan.

2. Korban luka berat, adalah korban yang mengalami cacat pada tubuh dan dirawat dalam waktu lebih dari 30 (tiga puluh) hari setelah terjadinya kecelakaan.

3. Korban luka ringan, merupakan korban yang tidak tertera pada penjelasan korban meninggal dunia dan korban luka berat.

\subsection{Biaya Kecelakaan Lalu Lintas}

Besar biaya yang ditimbulkan oleh kecelakaan lalu lintas yang mencakup kerugian harta benda, perawatan korban, dan biaya kerugian daya produksi korban. kecelakaan lalu lintas sedang. 


\subsubsection{Biaya Satuan Korban Kecelakaan Lalu Lintas (BSKO ( $_{\text {) }}$}

Biaya satuan korban kecelakaan lalu lintas merupakan biaya perawatan yang dibutuhkan setelah terjadi kecelakaan lalu lintas dapat dihitung menggunakan rumus :

$$
\begin{aligned}
& \operatorname{BSKO}_{j}\left(T_{n}\right)=\operatorname{BSKO}_{j}\left(T_{0}\right) \times(1+g)^{t} \\
& \text { keterangan: }
\end{aligned}
$$$$
\begin{aligned}
\mathrm{BSKO}_{\mathrm{j}}\left(\mathrm{T}_{\mathrm{n}}\right)= & \text { biaya satuan untuk } \\
& \text { kategori korban } \\
& \text { kecelakaan lalu lintas } \\
& \text { pada tahun } \mathrm{n}
\end{aligned}
$$$$
\mathrm{BSKO}_{\mathrm{j}}\left(\mathrm{T}_{0}\right)=\text { biaya satuan untuk }
$$$$
\text { kategori korban }
$$

kecelakaan lalu lintas pada tahun 2003

$\mathrm{g} \quad=$ tingkat inflasi biaya satuan kecelakaan (nilai default $\mathrm{g}=$ $11 \%)$

$$
\begin{array}{ll}
\mathrm{T}_{\mathrm{n}} & =\text { tahun perhitungan } \\
\mathrm{T}_{0} & =\text { tahun dasar } \\
& \text { perhitungan }
\end{array}
$$$$
\mathrm{t} \quad=\text { selisih tahun }
$$
perhitungan

$$
\mathrm{j}=\text { kategori korban }
$$

Besarnya biaya satuan korban kecelakaan lalu lintas menurut kategori

\begin{tabular}{|c|c|c|}
\hline No. & Kategori Korban & $\begin{array}{c}\text { Biaya Satuan } \\
\text { Kecelakaan } \\
\text { (Rp/Kecelakaan) }\end{array}$ \\
\hline 1 & $\begin{array}{l}\text { Korban meninggal } \\
\text { dunia }\end{array}$ & $119,016,000$ \\
\hline 2 & Korban luka berat & $5,826,000$ \\
\hline 3 & $\begin{array}{l}\text { Korban luka } \\
\text { ringan }\end{array}$ & $1,045,000$ \\
\hline
\end{tabular}
korban berdasarkan pedoman Pusat Litbang Prasarana Transportasi tahun 2006 dapat dilihat pada Tabel 1.
Tabel 1. Biaya Satuan Korban Kecelakaan Lalu Lintas BSKOj ( $\left.\mathbf{T}_{\mathbf{0}}\right)$

\subsubsection{Biaya Satuan Kecelakaan Lalu Lintas $\left(\right.$ BSKE $\left._{\mathbf{i}}\right)$}

Biaya satuan kecelakaan lalu lintas merupakan Biaya akibat kecelakaan lalu lintas untuk setiap kelas kecelakaan dapat dihitung menggunakan rumus :

$$
\operatorname{BSKE}_{\mathrm{i}}\left(\mathrm{T}_{\mathrm{n}}\right)=\operatorname{BSKE}_{\mathrm{i}}\left(\mathrm{T}_{0}\right) \times(1+\mathrm{g})^{\mathrm{t}} . .
$$

keterangan:

$\operatorname{BSKEi}\left(\mathrm{T}_{\mathrm{n}}\right)=$ biaya satuan untuk kelas kecelakaan lalu lintas pada tahun $n$

$\operatorname{BSKEi}\left(\mathrm{T}_{0}\right)=$ biaya satuan untuk kelas kecelakaan lalu lintas pada tahun 2003

g = tingkat inflasi biaya satuan kecelakaan (nilai default $\mathrm{g}=$ $11 \%)$

$\mathrm{T}_{\mathrm{n}} \quad=$ tahun perhitungan

$\mathrm{T}_{0} \quad=$ tahun dasar perhitungan

$\mathrm{t} \quad=$ selisih tahun perhitungan $=$ kelas kecelakaan 
Besar biaya satuan korban kecelakaan lalu lintas pada tahun 2003 dapat dilihat pada Tabel 2 (jalan antar kota) dan Tabel 3 (jalan kota).

Tabel 2. Biaya Satuan Korban Kecelakaan Lalu Lintas di Jalan Antar Kota BSKEi $\left(\mathbf{T}_{0}\right)$

\begin{tabular}{clc}
\hline No. & $\begin{array}{c}\text { Klasifikasi } \\
\text { Kecelakaan }\end{array}$ & $\begin{array}{c}\text { Biaya Satuan } \\
\text { Kecelakaan } \\
\text { (Rp/Kecelakaan) }\end{array}$ \\
\hline 1 & Fatal & $224,541,000$ \\
2 & Berat & $22,221,000$ \\
3 & Ringan & $9,847,000$ \\
4 & Kerugian Harta & $8,589,000$ \\
\hline
\end{tabular}

Sumber: Anonim, 2006

Tabel 3. Biaya Satuan Korban Kecelakaan Lalu Lintas di Jalan Kota BSKEi $\left(\mathbf{T}_{0}\right)$

\begin{tabular}{clc}
\hline No. & \multicolumn{1}{|}{$\begin{array}{c}\text { Klasifikasi } \\
\text { Kecelakaan }\end{array}$} & $\begin{array}{c}\text { Biaya Satuan } \\
\text { Kecelakaan } \\
\text { (Rp/Kecelakaan) }\end{array}$ \\
\hline 1 & Fatal & $131,205,000$ \\
2 & Berat & $18,997,000$ \\
3 & Ringan & $12,632,000$ \\
4 & Kerugian Harta & $15,725,000$ \\
\hline
\end{tabular}

Sumber: Anonim, 2006

\subsubsection{Besaran Biaya Korban Kecelakaan Lalu Lintas (BBKO)}

Besaran biaya korban kecelakaan lalu lintas yang terjadi pada suatu ruas jalan, persimpangan atau suatu wilayah dihitung pada tahun $\mathrm{n}$ dengan menggunakan rumus :

$$
\operatorname{BBKO}\left(\mathrm{T}_{\mathrm{n}}\right)=\sum_{\mathrm{j}=1}^{\mathrm{m}}\left(\mathrm{JKO}_{\mathrm{j}} \times \mathrm{BSKO}_{\mathrm{j}}\left(\mathrm{T}_{\mathrm{n}}\right)\right)
$$

keterangan:

$$
\begin{aligned}
\text { BBKO = } & \text { besar biaya korban } \\
& \text { kecelakaan lalu lintas }
\end{aligned}
$$

$$
\begin{aligned}
\mathrm{JKO}_{\mathrm{j}}= & \text { banyaknya kategori } \\
& \text { korban kecelakaan } \\
& \text { lalu lintas } \\
\mathrm{BSKO}_{\mathrm{j}}\left(\mathrm{T}_{\mathrm{n}}\right)= & \text { biaya satuan untuk } \\
& \text { kategori korban } \\
& \text { kecelakaan lalu lintas } \\
& \text { pada tahun } \mathrm{n} \\
\mathrm{j} \quad & \text { kategori korban }
\end{aligned}
$$

\subsubsection{Besaran Biaya Kecelakaan Lalu Lintas (BBKE)}

Besaran biaya kecelakaan lalu lintas dihitung pada tahun $\mathrm{n}$ dengan menggunakan rumus:

$$
\begin{aligned}
& \operatorname{BBKE}\left(\mathrm{T}_{\mathrm{n}}\right)=\sum_{\mathrm{i}=1}^{\mathrm{m}}\left(\operatorname{JKE}_{\mathrm{i}} \times \operatorname{BSKE}_{\mathrm{i}}\left(\mathrm{T}_{\mathrm{n}}\right)\right) \ldots \\
& \text { Keterangan: } \\
& \text { BBKE = besar biaya } \\
& \text { kecelakaan lalu lintas } \\
& \text { pada tahun } \mathrm{n} \\
& \mathrm{JKE}_{\mathrm{i}} \quad=\text { banyaknya kelas } \\
& \text { kecelakaan lalu lintas } \\
& \operatorname{BSKEi}\left(T_{n}\right)=\text { biaya satuan untuk } \\
& \text { kelas kecelakaan lalu } \\
& \text { lintas pada tahun } n \\
& \mathrm{i}=\text { kelas kecelakaan }
\end{aligned}
$$

\section{METODE PENELITIAN}

\subsection{Lokasi Penelitian}

Kabupaten Jember merupakan lokasi dari tugas akhir ini, tepatnya pada ruas jalan Kabupaten Jember yang mengalami kecelakaan yang telah diperoleh dari data Satlantas Polres Jember. 

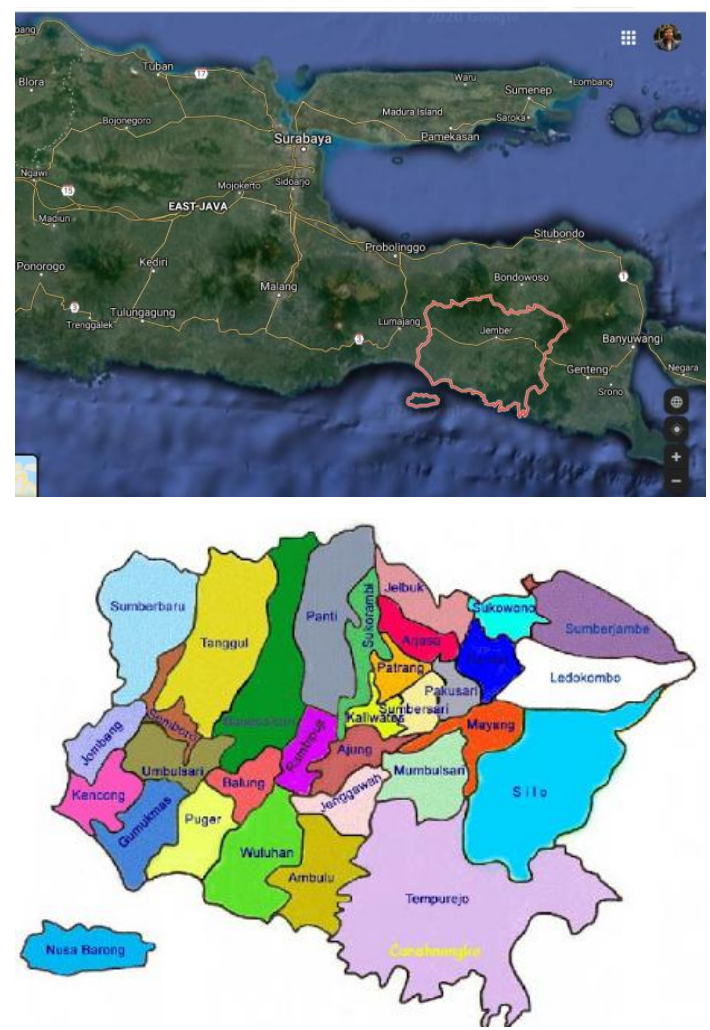

Gambar 1. Lokasi Penelitian

\subsection{Pengumpulan Data}

Penelitian ini memiliki satu macam data, yaitu data sekunder. Data sekunder Didapatkan dari Satlantas Polres Jember dengan merekapitulasi data kecelakaan di Kabupaten Jember dari tahun 2017-2019.

\subsection{Metode Analisis}

Pengerjaan untuk data yang didapat dilakukan melalui cara menganalisis dengan beberapa tahap, yaitu:

\subsubsection{Analisis Karakteristik Kecelakaan \\ Karakteristik kecelakaan yang} digunakan ditentukan berdasarkan tingkat keparahan korban, waktu kecelakaan, macam-macam kendaraan yang terlibat, usia korban, jenis kelamin, dan jenis pekerjaan korban dengan mengelompokkan sesuai dengan tahun terjadinya kecelakaan.

\subsubsection{Analisis Biaya Kecelakaan}

Perhitungan biaya kecelakaan menggunakan metode Gross Output dengan beberapa tahap, yaitu:

1. Biaya satuan korban kecelakaan lalu lintas (BSKOj).

2. Biaya satuan kecelakaan lalu lintas (BSKEi).

3. Besaran biaya korban kecelakaan lalu lintas (BBKO).

4. Besaran biaya kecelakaan lalu lintas (BBKE).

\section{HASIL DAN PEMBAHASAN}

\subsection{Karakteristik Kecelakaan}

\subsubsection{Hari}

Berdasarkan data yang diperoleh, karakteristik kecelakaan menurut hari di Kabupaten Jember sesuai dengan hari dalam seminggu. Rata-rata jumlah kecelakaan yang terjadi hampir sama setiap harinya.

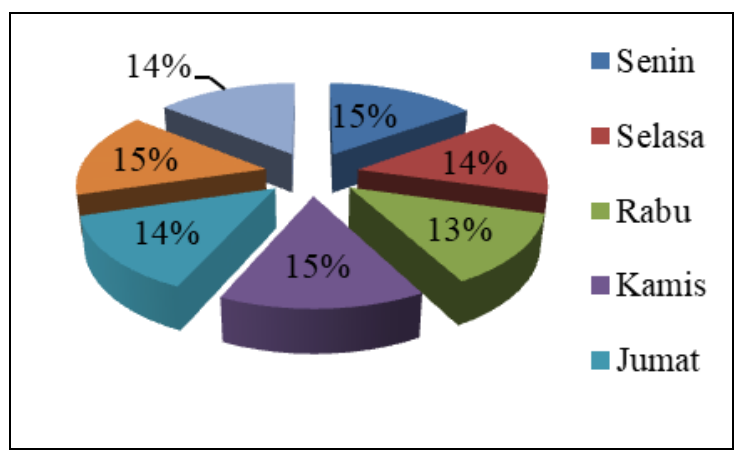

Gambar 2. Kecelakaan Berdasarkan Hari Tahun 2017-12019 


\subsubsection{Waktu kejadian}

Rentang waktu yang digunakan yaitu setiap 6 jam, jadi dalam sehari terbagi menjadi 4 kategori waktu seperti yang tercantum pada tabel dibawah ini. Waktu terjadinya kecelakaan lalu lintas terbanyak pada tahun 2017-2019 terdapat pada pukul 12.01-18.00 WIB dimana banyak masyarakat yang melakukan perjalanan untuk pulang.

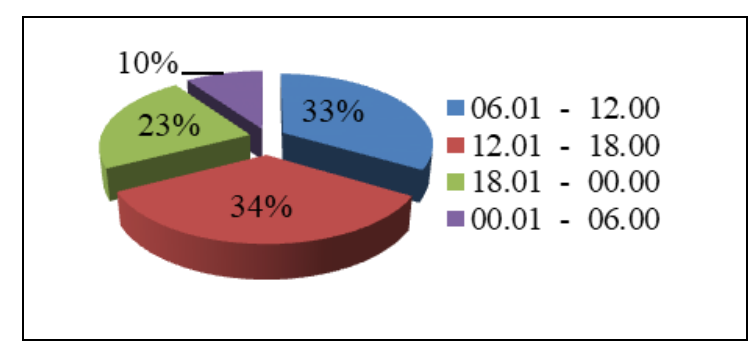

Gambar 3. Kecelakaan Berdasarkan Waktu Tahun 2017-2019

\subsubsection{Kelas korban}

Berdasarkan data yang diperoleh, karakteristik kecelakaan menurut kelas korban di Kabupaten Jember mencakup kriteria jenis korban. Dari data yang diperoleh didapatkan bahwa terjadi kenaikan jumlah korban kecelakaan pada tahun 2017 ke tahun 2018, dan dari tahun 2018 ke tahun 2019 mengalami penurunan korban kecelakaan.

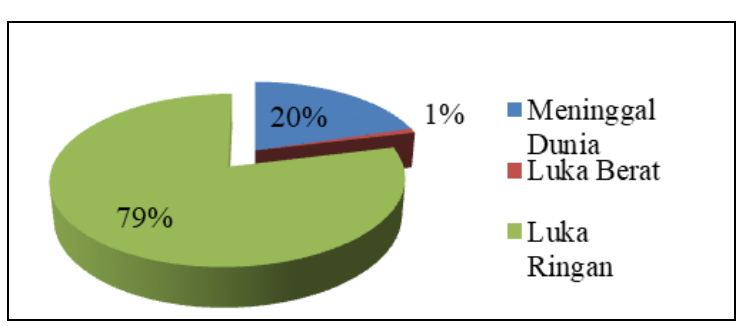

Gambar 4. Kecelakaan Berdasarkan Kelas Korban Tahun 2017-2019

\subsubsection{Tipe tabrakan}

Menurut data yang diperoleh, berdasarkan tipe tabrakan dikelompokkan menjadi 6 kategori. Selama tiga tahun, kecelakaan dengan tabrak lari yang sering terjadi dengan total 736 kejadian.

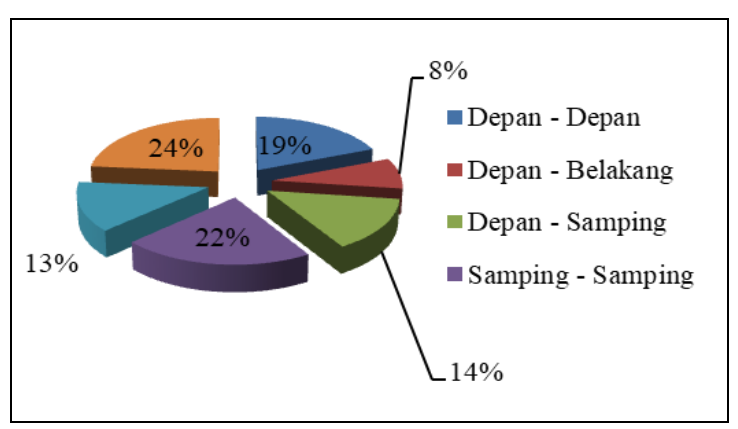

Gambar 5. Kecelakaan Berdasarkan Tipe Tabrakan Tahun 2017-2019

\subsubsection{Jenis kendaraan}

Jenis kendaraan yang sering terlibat kecelakaan setiap tahunnya yaitu sepeda motor dengan jumlah total sebanyak 5,095.

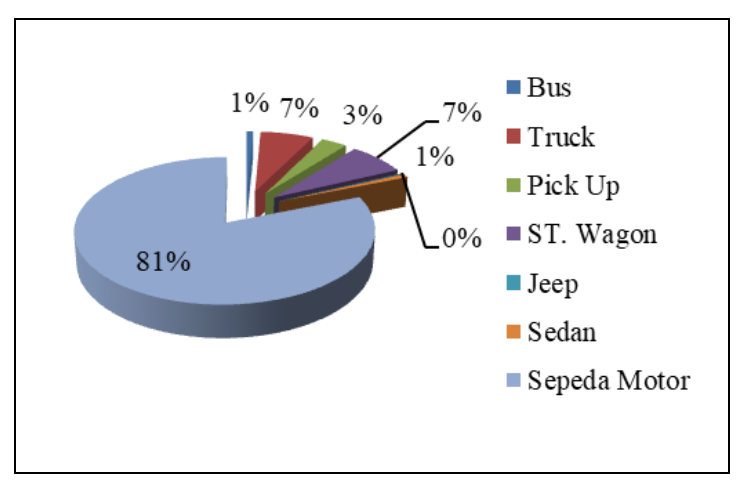

Gambar 6. Kecelakaan Berdasarkan Jenis Kendaraan Tahun 2017-2019

\subsubsection{Usia}

Masyarakat dengan rentang usia 1625 tahun yang sering terlibat dalam kecelakaan. 


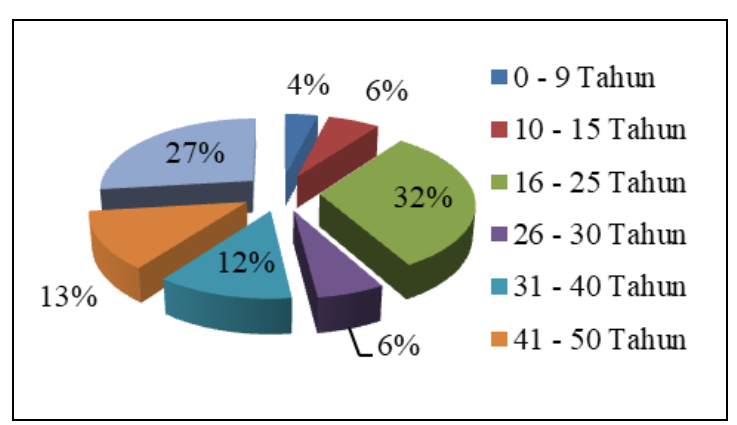

Gambar 7. Kecelakaan Berdasarkan Usia Tahun 2017-2019

\subsubsection{Jenis kelamin}

Kecelakaan lalu lintas banyak melibatkan masyarakat yang berjenis kelamin laki-laki yaitu sebanyak 3,582.

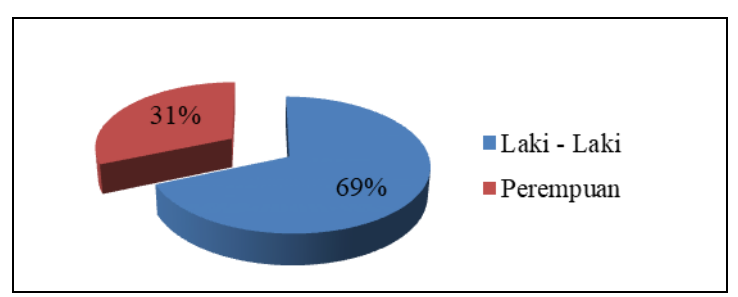

Gambar 8. Kecelakaan Berdasarkan Jenis Kelamin Tahun 2017-2019

\subsubsection{Jenis pekerjaan}

Menurut data yang didapat, dari tahun 2017 hingga 2019 masyarakat yang bekerja sebagai karyawan swasta dengan total sebanyak 3,128 orang terlibat dalam kecelakaan.

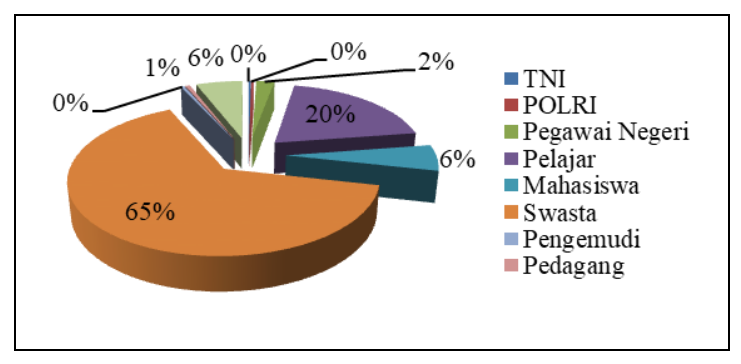

Gambar 9. Jumlah Kecelakaan

Berdasarkan Jenis Pekerjaan Tahun 20172019

\subsection{Biaya Kecelakaan}

Menurut Tabel 4 diperoleh bahwa biaya terbesar yaitu korban meninggal dunia dibandingkan dengan korban yang mengalami luka berat dan luka ringan akibat kecelakaan lalu lintas. Untuk total biaya korban kecelakaan lalu lintas pada tahun 2017 sebesar Rp. 58,406,958,961.00, untuk tahun 2018 total biaya korban kecelakaan lalu lintas sebesar Rp. 58,243,003,229.00, dan untuk tahun 2019 total biaya korban kecelakaan lalu lintas sebesar Rp. 45,360,270,990.00.

Menurut Tabel 5 dapat diketahui bahwa kelas kecelakaan dengan kerugian harta benda merupakan kecelakaan yang menimbulkan biaya terbesar pada jalan kota. Total biaya kecelakan dari tahun 2017 ke tahun 2018 mengalami kenaikan sebesar $20.68 \%$, sementara untuk tahun 2018 ke tahun 2019 mengalami penurunan sebesar $21.73 \%$. Total biaya kecelakaan tahun 2017 yaitu sebesar Rp. 13,032,950,393.00, untuk tahun 2018 total biaya kecelakaan yaitu sebesar Rp. 15,727,733,090.00, dan untuk tahun 2019 total biaya kecelakaan yaitu sebesar Rp. $12,310,271,850.00$. 
Tabel 4. Biaya Korban Kecelakaan Kabupaten Jember tahun 2017-2019

\begin{tabular}{cccccc}
\hline \multirow{2}{*}{ Tahun } & \multicolumn{3}{c}{ Jenis Korban } & \multirow{2}{*}{ Total (Rp.) } \\
\cline { 2 - 4 } & Meninggal Dunia (Rp.) & Luka Berat (Rp.) & Luka Ringan (Rp.) & \\
\hline 2017 & $56,481,179,970$ & $103,581,637$ & $1,822,197,354$ & $58,406,958,961$ \\
2018 & $56,162,972,009$ & $143,564,292$ & $1,936,466,928$ & $58,243,003,229$ \\
2019 & $43,727,668,560$ & $84,069,180$ & $1,548,533,250$ & $45,360,270,990$ \\
\hline
\end{tabular}

Tabel 5. Biaya Kecelakaan Kabupaten Jember Tahun 2017-2019 (Jalan Kota)

\begin{tabular}{cccccc}
\hline \multirow{2}{*}{ Tahun } & \multicolumn{5}{c}{ Jenis Korban } \\
\cline { 2 - 5 } & $\begin{array}{c}\text { Kecelakaan } \\
\text { Fatal (Rp.) }\end{array}$ & $\begin{array}{c}\text { Kecelakaan } \\
\text { Berat (Rp.) }\end{array}$ & $\begin{array}{c}\text { Kecelakaan } \\
\text { Ringan (Rp.) }\end{array}$ & $\begin{array}{c}\text { Kecelakaan } \\
\text { Kendaraan (Rp.) }\end{array}$ & Total (Rp.) \\
\hline 2017 & $2,871,040,406$ & $337,751,519$ & $4,232,599,124$ & $5,591,559,344$ & $13,032,950,393$ \\
2018 & $5,173,045,776$ & $140,437,222$ & $4,311,196,754$ & $6,103,053,338$ & $15,727,733,090$ \\
2019 & $4,077,851,400$ & $147,606,690$ & $3,337,121,760$ & $4,747,692,000$ & $12,310,271,850$ \\
\hline
\end{tabular}

Tabel 6. Biaya Kecelakaan Kabupaten Jember Tahun 2017-2019 (Jalan Antar Kota)

\begin{tabular}{cccccc}
\hline \multirow{2}{*}{ Tahun } & \multicolumn{4}{c}{ Jenis Korban } & \multirow{2}{*}{ Total (Rp.) } \\
\cline { 2 - 5 } & $\begin{array}{c}\text { Kecelakaan } \\
\text { Fatal (Rp.) }\end{array}$ & $\begin{array}{c}\text { Kecelakaan } \\
\text { Berat (Rp.) }\end{array}$ & $\begin{array}{c}\text { Kecelakaan } \\
\text { Ringan (Rp.) }\end{array}$ & $\begin{array}{c}\text { Kecelakaan } \\
\text { Kendaraan (Rp.) }\end{array}$ & \\
\hline 2017 & $27,023,852,449$ & $2,066,528,735$ & $9,211,470,721$ & $9,632,197,780$ & $47,934,049,684$ \\
2018 & $51,458,195,695$ & $903,490.305$ & $12,132,489$ & $10,762,409,517$ & $63,136,228,006$ \\
2019 & $23,677,848,450$ & $1,159,269,570$ & $7,716,700,020$ & $8,084,653,920$ & $40,638,471,960$ \\
\hline
\end{tabular}

Total biaya kecelakan lalu lintas dari tahun 2017 ke tahun 2018 mengalami kenaikan sebesar $31.72 \%$, sementara dari tahun 2018 ke tahun 2019 mengalami penurunan sebesar $35.63 \%$. Total biaya kecelakaan lalu lintas tahun 2017 yaitu sebesar Rp. 47,934,049,684.00, untuk tahun 2018 total biaya kecelakaan lalu lintas yaitu sebesar Rp. 63,136,228,006.00, dan untuk tahun 2019 total biaya kecelakaan lalu lintas yaitu sebesar Rp. 40,638,471,960.00 (Tabel 6).

\section{SIMPULAN DAN SARAN}

\subsection{Simpulan}

Selama periode 2017-2019 di Kabupaten Jember terjadi sebanyak 3,543 kecelakaan lalu lintas, dengan karakteristik yang paling dominan yaitu kecelakaan ringan yang melibatkan masyarakat yang berjenis kelamin laki-laki dengan usia 1625 tahun dengan pekerjaan sebagai pegawai swasta dan mengendarai sepeda motor. 
Menurut analisis biaya kecelakaan selama tahun 2017-2019 dengan menggunakan metode Gross Output, didapatkan hasil yaitu untuk total biaya korban kecelakaan sebesar Rp. 162,010,233,179.-. Total biaya kecelakaan pada jalan kota sebesar Rp. 41,070,955,333.-. Total biaya kecelakaan pada jalan antar kota sebesar Rp. 151,708,749,650.--

\subsection{Saran}

Perhitungan biaya kecelakaan sebaiknya dilakukan rutin setiap tahun supaya perkembangan kecelakaan dapat terlihat sehingga dapat dilakukan pencegahan dan penanganan yang baik.

\section{DAFTAR PUSTAKA}

Anonim. (2006). Pedoman Perhitungan Besaran Biaya Kecelakaan Lalu Lintas dengan Menggunakan Metoda The Gross Output (Human Capital). Jakarta: Pusat Litbang Prasarana Transportasi.

Azizurrohman, M. F., Hayati, N. N., \& Kriswardhana, W. (2018). Peluang Kecelakaan Sepeda Motor Berdasarkan Karakteristik Pengendara di Kabupaten Jembe. Universitas Jember.

Farida, I., \& Santosa, W. (2018). Keselamatan angkutan bus di Kabupaten Garut. Jurnal Transportasi, 18(3), 211-218. https://doi.org/https://doi.org/10.265 93/jt.v18i3.3159.\%25p
Kriswardhana, W., Sulistyono, S., Ervina, I., Supriyanto, D., Hayati, N. N., Wicaksono, A., \& Ramadhani, R. A. (2019). Modeling The Probability Of Speeding Behaviour And Accident Involvement Using Binary Logistic Regression. Journal of Indonesia Road Safety, 2(3), 149-158.

Ogden, K. W. (1996). Safer roads. A guide to road safety engineering. Aldershot, UK: Avebury Technical.

Raj, C. K. P., Datta, S. S., V, J., Singh, Z., \& V, S. (2011). Study of knowledge and behavioural patterns with regard to road safety among high school children in a rural community in Tamil Nadu, India. Indian Journal of Medical Specialities, 2(2). https://doi.org/10.7713/ijms.2011.00 28

Rozy, R. F. (2010). Evaluasi Biaya Kecelakaan Mahasiswa Universitas Muhammadiyah Malang. Institut Teknologi Sepuluh Nopember.

Sugiyanto, G. (2017). The cost of traffic accident and equivalent accident number in developing countries (case study in Indonesia). ARPN Journal of Engineering and Applied Sciences, 12(2), 389-397. 